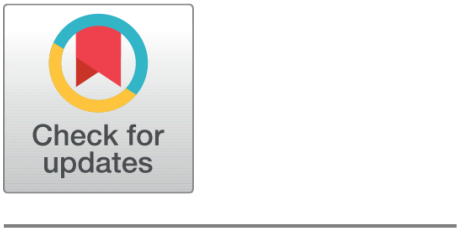

OPEN ACCESS

Received: 30.08.2021

Accepted: 04.10.2021

Published: 03.11.2021

Citation: Bayramova NK, Sultanova NF, Aliyeva DR, Huseynova IM (2021) Lipid Peroxidation Level and Peroxidase Activity in (Vitis vinifera L.) Leaves Infected with Grapevine Leafroll-Associated Virus 3. Indian Journal of Science and Technology 14(36): 2842-2849. https://doi.org/ 10.17485/IJST/v14i36.1612

* Corresponding author.

irada.huseynova@science.az

Funding: None

Competing Interests: None

Copyright: (c) 2021 Bayramova et al. This is an open access article distributed under the terms of the Creative Commons Attribution License, which permits unrestricted use, distribution, and reproduction in any medium, provided the original author and source are credited.

Published By Indian Society for Education and Environment (iSee)

ISSN

Print: 0974-6846

Electronic: 0974-5645

\section{Lipid Peroxidation Level and Peroxidase Activity in (Vitis vinifera L.) Leaves Infected with Grapevine Leafroll-Associated Virus 3}

\author{
Nargiz Kamal Bayramova ${ }^{1}$, Nargiz Fakhraddin Sultanova ${ }^{2}$, \\ Durna Rafail Aliyeva2 ${ }^{2}$, Irada Mammad Huseynova3*
}

1 Junior researcher, Institute of Molecular Biology and Biotechnologies, Azerbaijan National Academy of Sciences

2 Associate professor, PhD in biology, Institute of Molecular Biology and Biotechnologies, Azerbaijan National Academy of Science

3 Professor. Director, Academician, Doctor of biological sciences, Institute of Molecular Biology and Biotechnologies, Azerbaijan National Academy of Sciences

\section{Abstract}

Objective: Grapevine (Vitis vinifera L.) is one of the major crops widely cultivated for the wine industry, as well as for the production of fresh and dried fruit in Azerbaijan. Grapevine leafroll disease (GLD) affects the vines throughout the world and is considered the most economically destructive among all virus and virus-like diseases. Vineyard surveys were conducted to determine the virus infection in the major grapevine growing region of Azerbaijan during 2019-2020. Methods/Statistical analysis: Forty-six samples were collected from grapevine fields and screened by rapid one-step assay AgriStrip and double-antibody sandwich Enzyme-linked immunosorbent assay (DASELISA). In our study, the levels of malondialdehyde (MDA), hydrogen peroxide $\left(\mathrm{H}_{2} \mathrm{O}_{2}\right)$, pigments, relative water content (RWC), alterations in the activities of peroxidase enzymes (the activities of ascorbate peroxidase (APO), benzidine peroxidase (BPO) and guaiacol peroxidase (GPO) were investigated. Findings: The results revealed that tested samples were infected with Grapevine leafrollassociated virus 3 (GLRaV-3), however, no sample was found infected with other Grapevine leafroll-associated viruses. Changes in the levels of MDA, $\mathrm{H}_{2} \mathrm{O}_{2}$, pigments, RWC, alterations in the activities of peroxidase enzymes were studied. Significant reduction in green pigments like chlorophylls $(a, b$ and total) and a gradual reduction in carotenoids were observed in all infected species. Obtained results showed that the level of RWC and the amount of hydrogen peroxide had increased in all infected leaves. The activities of APO, BPO and GPO were observed to increase in virus-infected leaves compared to the healthy control. Based on the results, it can be concluded that the effect of GLRaV-3 was more destructive in the N2 sample. The antioxidant defense system works more effectively in the N5 sample and this plant is more resistant to viral infection. Novelty: These results indicate that GLRaV-3 was the only most prevalent endemic viral pathogen of grapevine in the dominantly warm 
humid continental climate of our country. All variable physiological parameters are assessed as the plant's response to the pathogen.

Keywords: activity; chlorophyll; hydrogen peroxide; malondialdehyde; peroxidase; virus disease

\section{Introduction}

Grapevine (Vitis vinifera L.) is one of the important and valuable plants cultivated from ancient times to nowadays in many countries worldwide. Grapevines are sensitive to a wide range of viral diseases. Phytopathogenic viruses, which cause a very wide range of symptoms in diseased plants, also moderate host metabolic processes. Therefore, it leads to major losses in crop yield and its quality. The age of the infected plant, specific virus-host combinations and interactions as well as the virulence of the virus determine the level of the negative effect of plant viruses.

The occurrence of single and mixed viral infections often leads to an exacerbation of the symptoms and crop losses. This may be due to the great potential of perennial viruses for molecular variability. Genetic variation plays a significant role in adaptation processes of viruses under unsatisfied conditions and increases the level of competitiveness, tolerance and overwintering survival. The virus infections associated with the main complex viral diseases of vines including grapevine leafroll diseases (GLD), corky rugose wood (CRW), and infectious degeneration (Fanleaf) are the most spread and threatening viruses of grapevine. It has been reported that most viruses of grapevine diseases are part of various pathogen complexes depending on the variety and composition of the vineyard. Among them, GLD is considered a very dangerous infection for wine grapes in the world and causes a variety of contrasting symptoms in red and white-berried grapevine cultivars. Generally, symptoms are more dramatic in red grape varieties than in white ones. Typical symptoms in late July or early August are visible. During summer, symptoms extend upwards to other leaves and leaf coloration spreads. The main vein remains green, the areas around it become reddish purplish. In the later stages of the infection, the leaves turn inwards, which explains the name of the disease ${ }^{(1)}$. Virus-infected plants frequently show mosaic, chlorosis and mottling symptoms systemically on leaves ${ }^{(2)}$. All these changes are highly related to reducing rates of photosynthetic activity, induction of physiological and metabolic changes in grapevine leaves. It is known that most viruses from the family Closteroviridae, related to GLD and GLRaVs, show high prevalence in grapevines worldwide. However, GLRaV-3 can be transmitted by soft scale insects (Homoptera: Coccidae) or mealybugs (Homoptera: Pseudococcidae) and also by grafting, belongs to the genus Ampelovirus and is regarded as the most important causative agent among all GLRaVs ${ }^{(3)}$. Symptoms of GLD could vary depending on the season, the species of grape cultivar, and the climatic conditions of the growing region. Besides, some species can be completely symptomless, for example, some rootstocks and certain white $V$. vinifera cultivars. Symptoms on leaves firstly appear in early to mid-summer and until late autumn, then they increase on a large scale ${ }^{(4)}$.

Grape leafroll disease because of causing a great yield loss, is considered the most economically harmful among grape viral diseases ${ }^{(5)}$. GLRaV-3 has been reported as the most virulent and dangerous virus infection among all GLRaVs, in most grapevinegrowing regions all over the world, also in Azerbaijan. Gradual reduction of vines and high yield losses, including virus-like symptoms, are often accompanied by a decrease in the quality of grape juice, a decrease in soluble solid compounds, and an increase in phenolic substances and titratable acidity. Various significant aspects of plant metabolism can also be disrupted as well as qualitative parameters such as the amount of aromatic compounds in grapes. Such changes as disruption of photosynthesis, transfer of respiratory assimilators and the life cycle of the vine, as well as suppression of plant 
growth and development, a decrease in such qualities as survival, a decrease in the drought resistance of the vine, etc., are also can be observed during viral infections of the plant.

Virus diseases in the grapevine have detrimental effects on the agronomic, ecological performance, and morphological changes of vines. In addition to reduced yield and quality, viruses also damage photosynthesis, chloroplast level, functions and ultrastructure, accumulation of photoassimilates ${ }^{(6)}$. Viruses also may determine leaf and cluster of morphological modifications which aid phenotypic expression of disease symptoms and exertion of plenty of other pathological changes in the plant. Defense responses to plant-virus interactions are related to the accumulation of reactive oxygen species (ROS). ROS play an important role in many processes in plants ${ }^{(7)}$. However, they are free radicals and reactive molecules, the excess of them may be harmful to the plant and besides the result can be senescence or cell death ${ }^{(8)}$. Peroxidases are oxidation-reduction enzymes involved in cell wall building, such as oxidation of phenols, suberization and lignification of host plant cells that protect plants from pathogens ${ }^{(9)}$. Their catalyzation increases defense cell wall proteins, these are proteins involved in the hypersensitive response. Changes in plant metabolism and indices of physiological and biochemical processes that are responsible for plant viability under stress ensure the plant tolerance degree to various viruses ${ }^{(10)}$. Currently, the researchers have focused on the major physiological and metabolic changes in plant response to viruses and negative environmental factors. Under natural conditions, the grapevine is exposed to the effect of numerous pathogens. Therefore, it is very difficult to distinguish the effects of each pathogen individually. Because of that, physiological consequences of grapevine leafroll diseases need more research.

We aimed to study the contents of $\mathrm{MDA}, \mathrm{H}_{2} \mathrm{O}_{2}$, photosynthetic pigments, RWC, the activities of peroxidase enzymes in GLRAV-3 infected plants.

\section{Materials and Methods}

\subsection{Plant material}

The phytopathological surveys were carried out to identify GLD symptoms in Jalilabad ( $\left.39^{\circ} 12^{\prime} 00.0^{\prime \prime} \mathrm{N} 48^{\circ} 18^{\prime} 00.0^{\prime \prime} \mathrm{E}\right)$, the major grapevine-growing region of Azerbaijan, during 2019-2020. Forty-six leaf samples with virus-like symptoms were collected from field-grown grapevines. Symptomless plant leaves were also used as a control. Collected leaf samples were taken to the laboratory properly and kept at $4^{\circ} \mathrm{C}$ until they were processed.

\subsection{Virus detection and identification}

The possible presence of grapevine leafroll-associated viruses in the original samples was checked by rapid one-step assay AgriStrip and double-antibody sandwich Enzyme-linked immunosorbent assay (DAS-ELISA) using antisera against Grapevine fanleaf virus (GFLV) and GLRaV-1, -2, -3, -4, GLRaV 1+3 which were developed by Bioreba AG (Reinach, Switzerland) and were used according to the manufacturer's instructions. The completely virus-free plants were used as the control in biochemical experiments.

\subsection{Measured parameters}

\subsubsection{The relative water content (RWC) assay}

RWC of leaves was measured according to Smart and Bingham ${ }^{(11)}$. After sampling, leaf discs were taken and the fresh weight of a mixed sample of five young leaves was immediately determined and then immersed in distilled water, in Petri dishes, for 6 hours at room temperature. The turgid weight was measured. The leaves were then blotted dry and weighed before oven drying at $60^{\circ} \mathrm{C}$ for $24 \mathrm{~h}$ and their dry weight was recorded. To calculate relative water content, the following formula was used:

$$
\mathrm{RWC}(\%)=[(\mathrm{FW}-\mathrm{DW}) /(\mathrm{TW}-\mathrm{DW})] \times 100
$$

Where, FW is fresh weight, DW-dry weight, and TW- turgid weight ${ }^{(11)}$.

\subsubsection{Malondialdehyde assay}

The intensity of the lipid peroxidation was determined based on the MDA amount in leaf samples of healthy and virus-infected plants. Malondialdehyde was quantified by the spectrophotometric method based on the reaction with thiobarbituric acid at wavelengths of 532 and $600 \mathrm{~nm}$ and calculated according to the following formula: $\mathrm{A}_{(\mathrm{mM} / \mathrm{g} \text { fresh biomass })}=\left(\mathrm{D}_{532}-\mathrm{D}_{600}\right) / 46.5^{(12)}$. 


\subsubsection{Hydrogen peroxide assay}

Hydrogen peroxide was quantified spectrophotometrically using the Bellincampi (2000) method ${ }^{(13)}$. The method is based on the oxidation of $\mathrm{Fe}^{+2}$ to $\mathrm{Fe}^{+3}$ ions in the presence of $\mathrm{H}_{2} \mathrm{O}_{2}$. The products obtained were stained with xylene orange and measured at a wavelength of $560 \mathrm{~nm}$ using the spectrophotometric method (ULTROSPEC 3300 PRO "Amersham", USA). Hydrogen peroxide solutions of various concentrations prepared in acetone were used to construct the calibration curve.

\subsubsection{Determination of photosynthetic pigments}

The chlorophyll content was determined by Porra et al. ${ }^{(14)}$.

$$
\begin{aligned}
& \text { Chl } a(\mathrm{nmol} / \mathrm{ml})=14.21 \text { A } 663-3.01 / A 645 \\
& \text { Chl } b(\mathrm{nmol} / \mathrm{ml})=25.23 \text { A } 645-5.16 \text { A } 663 \\
& \text { Chl } a+b(\mathrm{nmol} / \mathrm{ml})=22.22 \text { A } 645-9.05 \text { A } 663
\end{aligned}
$$

The content of carotenoids was determined by Wettstein ${ }^{(15)}$.

$$
\text { Carotenoids }(\mathrm{mg} / 1)=4.695 \cdot \mathrm{A} 440.5-0.268 \mathrm{Chl}(a+b)
$$

\subsection{Extract preparation for enzyme assays}

The leaf samples $(0.5 \mathrm{~g})$ were homogenized using a mortar and pestle. For this purpose, $2 \mathrm{ml}$ of an ice-cold extraction buffer (100 mM potassium phosphate buffer, $\mathrm{pH} 7.0,0.1 \mathrm{mM}$ EDTA) was applied. After the filtration of the homogenate through a muslin cloth, it was centrifuged at $16,000 \times \mathrm{g}$ for $15 \mathrm{~min}$. The enzyme activity was determined in the supernatant fraction. During the experiment, the temperature was maintained at $4^{\circ} \mathrm{C}^{(16)}$.

\subsubsection{The ascorbate peroxidase activity}

The spectrophotometric method with some modifications was used to determine the APO activity (APO, EC 1.11.1.11) ${ }^{(16)}$. Thus, the rate of the decomposition reaction of hydrogen peroxide by ascorbate to form water and dehydro-ascorbate was determined. Optical density was measured at $290 \mathrm{~nm}$. The activity was expressed in $\mu \mathrm{mol}$ (ascorbate) $/ \mathrm{mg}$ (protein) $/ \mathrm{min}$ based on a molar extinction coefficient: $\varepsilon=2.8 \mathrm{mM}^{-1} \mathrm{~cm}^{-1}$.

\subsubsection{The guaiacol-type peroxidase activity}

The enzyme (GPO, EC 1.11.1.7) activity was determined by the change in optical density of the reaction mixture for 3 min at 470 $\mathrm{nm}^{(17)}$. The GPO activity was calculated as $\mu \mathrm{mol}$ (oxidized guaiacol) $/ \mathrm{mg}$ (protein) /min assuming the extinction coefficient: $\varepsilon=26.6 \mathrm{mM}^{-1} \mathrm{~cm}^{-1}$.

\subsubsection{The benzidine-type peroxidase activity}

The enzyme (BPO EC 1.11.1.7.) activity was measured by the increase in optical density of the reaction mixture for $1 \mathrm{~min}$ at $590 \mathrm{~nm}^{(18)}$. The activity was calculated in $\mu \mathrm{mol}$ (benzidine product) $\mathrm{mg} / \mathrm{min}$ (protein) assuming extinction coefficient: $\varepsilon=39$ $\mathrm{mM}^{-1} \mathrm{~cm}^{-1}$.

\subsection{Statistical analysis}

Statistical analysis was performed in 3 biological replicates using the computer program Excel 2016. In all figures, mean values are shown with error bars representing standard errors of the mean. The significance of differences between mean values was compared by Student's T-test. Differences at $\mathrm{P} \leq 0.05$ were considered significant.

\section{Results and Discussion}

During surveys performed in Jalilabad vineyards, virus-like symptoms as leaf reddening, greening of main veins, red and dark-red spots on the leaves, mosaics, leaf yellowing, inward leaf rolling, decay, or irregular ripening of berries were observed (Figure 1). Contrary to the white grape varieties, typical viral symptoms were detected in leaves of red and black grape varieties.

The field average cumulative percentage of these viruses affecting plants was $28 \%$. Immunostrip-test bands and the results of ELISA completely coincided. The results revealed that tested samples were infected with GLRaV-3, however, no sample was 


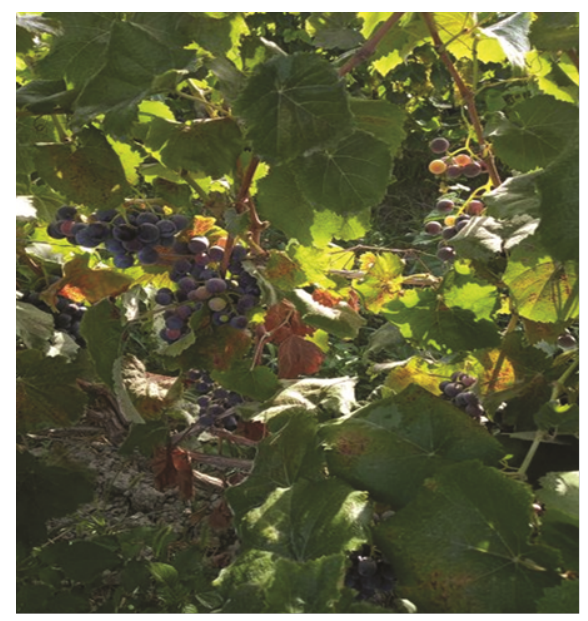

A

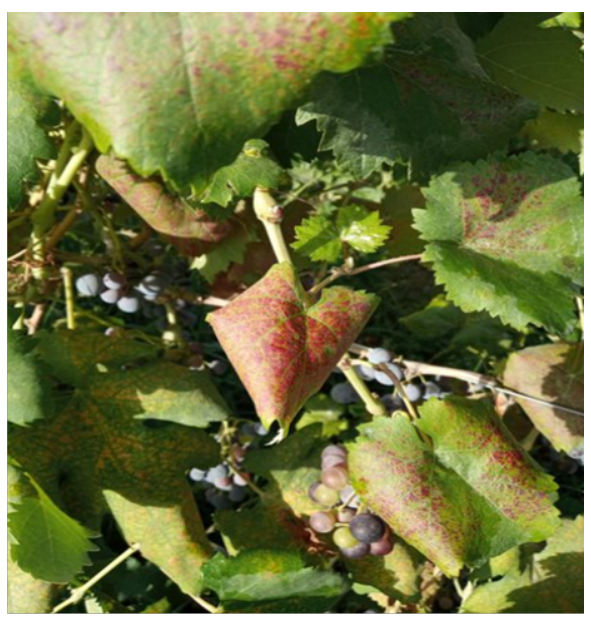

B

Fig 1. Symptoms on the grape leaves infected with GLRaV- 3. A - Extensive leaf yellowing, stunting and leaf deformation. B- Leaf curling and discoloration.

found infected with other GLD viruses. The presence of the virus was confirmed by all ELISA tests. Twenty-five out of forty-six grapevine samples were tested positive for GLRaV-3. These results indicate that GLRaV-3 was the only most prevalent endemic viral pathogen of grapevine in the dominantly warm humid continental climate of our country. Samples of GLRaV-3 infected plants and healthy plants, which were completely virus-free, were subjected to the biochemical and physiological analyses.

To understand plant-pathogen interaction and plant responses to virus infections, metabolic changes caused by a viral infection in plants must be clarified. Therefore, in our study, the changes in the rate of metabolic compounds such as malondialdehyde, hydrogen peroxide, pigments, relative water content (RWC), and alterations in the activities of peroxidase enzymes caused by GLRaV-3 were analyzed in naturally grown grapevine plants. It is known that the transmission of signals via ROS plays an important role in resistance to pathogens. When the plants are infected, the activity of peroxidases that block the damaged zones in these genotypes, and the amounts of phenolic compounds increase.

The amounts of hydrogen peroxide, malondialdehyde, and leaf relative water content were found to change (Table 1). Moreover, other responses of symptomatic plants to viral diseases were also studied. In all infected samples, a gradual reduction of chlorophylls $(\mathrm{Chl} \mathrm{a}+\mathrm{Chl} b)$ was observed during pathogenesis. The carotenoid content was not significantly affected by GLRaV-3 infection (Figure 2).

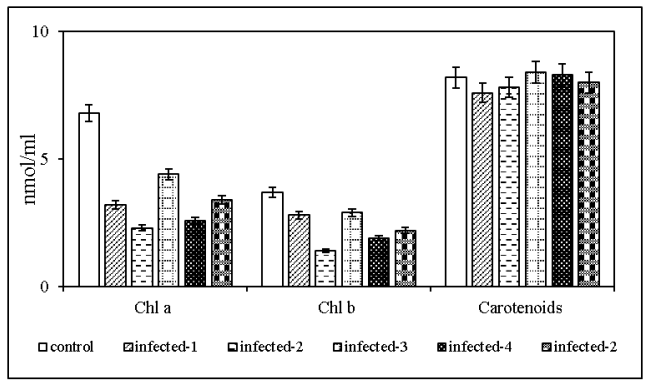

Fig 2. Changes in amounts of photosynthetic pigments in healthy and virus-infected grapevine leaves.

As seen in the table, the MDA amount sharply increased in healthy plant leaves compared to infected leaves. This increase was $\sim 3.5$ and 3.2 -fold in the 2nd and 4 th samples, respectively.

The increase in MDA content and decline in chlorophyll a, chlorophyll b, RWC of infected grape N2 were much greater compared to all other infected plants (Table 1). Chlorophyll content in the virus-infected grapevine leaf sample N2 (2.3 \pm 0.12 $\mathrm{nmol} / \mathrm{ml})$ decreased by $66 \%$ when compared with that of the control plant leaf $(6.8 \pm 0.48 \mathrm{nmol} / \mathrm{ml})$. Similarly, Chl b content was found to decrease by $62 \%$ in the virus-infected grapevine leaf $(1.4 \pm 0.07 \mathrm{nmol} / \mathrm{ml})$ compared to the control leaf $(3.7 \pm 0.19$ 
Table 1. Changesin amounts of hydrogen peroxide $\left(\mathrm{H}_{2} \mathrm{O}_{2}\right)$, malondialdehyde (MDA), and leaf relative water content (RWC) in healthy andvirus-infected grapevine leaves

\begin{tabular}{llll}
\hline Plant samples & $\mathrm{H}_{2} \mathrm{O}_{2}, \mu \mathrm{mol} / \mathrm{g}$ & $\mathrm{MDA}, \mathrm{mM} / \mathrm{g}$ fresh biomass & RWC, \% \\
\hline Control (healthy) & $0.53 \pm 0.04$ & $2.24 \pm 0.11$ & $84.0 \pm 3.0$ \\
Infected N1 & $0.81 \pm 0.06^{* *}$ & $6.85 \pm 0.34^{* * *}$ & $74.0 \pm 2.4^{*}$ \\
PN1 vs control & $\mathrm{P}<0.01$ & $\mathrm{P}<0.001$ & $\mathrm{P} 0.05$ \\
Infected N2 & $0.62 \pm 0.04$ & $7.83 \pm 0.55^{\star * *}$ & $61.0 \pm 1.8^{* * *}$ \\
PN2 vs control & $<0.1$ & $<0.001$ & $<0.001$ \\
Infected N3 & $0.61 \pm 0.04$ & $6.29 \pm 0.44^{* * *}$ & $64.0 \pm 2.0^{* * *}$ \\
PN3 vs control & $<0.1$ & $<0.001$ & $<0.001$ \\
Infected N4 & $0.82 \pm 0.06^{* *}$ & $7.22 \pm 0.51^{* * *}$ & $70.0 \pm 2.2^{* *}$ \\
PN4 vs control & $<0.01$ & $<0.001$ & $<0.01$ \\
Infected N5 & $0.89 \pm 0.07^{* *}$ & $6.29 \pm 0.50^{* * *}$ & $71.0 \pm 2.1^{* *}$ \\
PN5 vs control & $<0,01$ & $<0.001$ & $<0.01$ \\
\hline
\end{tabular}

Significance levels: ${ }^{\mathrm{ns}}-\mathrm{P}<0.1$; $^{*} \mathrm{P}<0.05$; $^{* *}-\mathrm{P}<0.01$; $^{* * *}-\mathrm{P}<0.001$

$\mathrm{P}$-values were calculated by $\mathrm{t}$-test calculator for 2 independent means in regime of two-tailed hypothesis(https://www.socscistatistics.com/tests/studentttest/d efault2.aspx)

$\mathrm{nmol} / \mathrm{ml}$ ). RWC declined by $24 \%$ in the virus-infected leaf samples. The amounts of carotenoids did not change significantly in the leaf samples infected with GLRaV-3 compared to the healthy plant samples. A relative decrease was observed only in the $\mathrm{N} 1$ and $\mathrm{N} 2$ samples compared to the control leaves (by 7.3\% and 4.8\%, respectively). Based on the results, it can be concluded that the effect of GLRaV-3 was more destructive in the N2 sample.

The activity of APO, GPO, and BPO enzymes was observed to increase in the infected plant samples compared to the healthy plants (Figure 3). But this increase was more pronounced in the N5 sample ( 1.5 and $\sim 1.8$-fold for APO and BPO, respectively). The activity of guaiacol peroxidase, which is involved in the lignification of cell walls, increased more in the N1 and N2 samples infected with the virus (1.77 and 1.72-fold, respectively). The amount of $\mathrm{H}_{2} \mathrm{O}_{2}$, one of the reactive oxygen species, was also higher in these samples than in others. This indicates that these samples are more affected by stress. The amount of $\mathrm{H}_{2} \mathrm{O}_{2}$ in grape samples infected with GLRaV-3 increased 1.2-1.7-fold compared to the healthy samples. The highest increase (67\%) was observed in the N5 sample. The observed increase in the amount of hydrogen peroxide correlated with the activities of $\mathrm{APO}$ and BPO. This fact confirms that the antioxidant defense system works more effectively in the N5 sample and this plant is more resistant to viral infection.

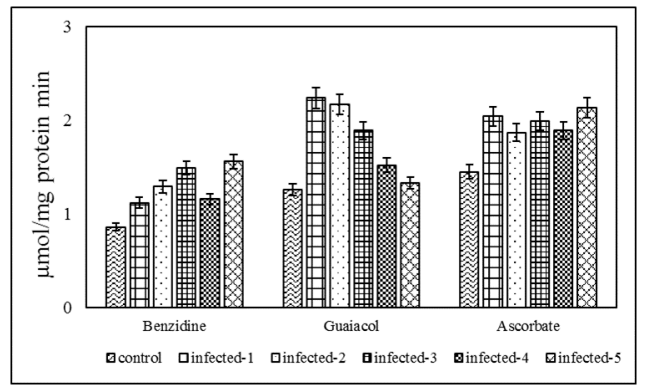

Fig 3. Activities ofascorbate peroxidase (APO), guaiacol peroxidase (GPO), and benzidine peroxidase (BPO) in virus-infected grapevine plants.

Being the principal light-absorbing pigments, chlorophylls are key components of photosynthesis in plants. The obtained results revealed that the GLRaV-3 infected plants showed a more significant reduction in chlorophyll content than healthy plants. As a result of the physiological studies of grapevine leaves, a significant decrease in the chlorophyll content leading to the inhibition of the photosynthetic activity was observed. This decrease may be due to the disintegration of chlorophyll or inhibition of its synthesis by the growing pathogen inside the leaf tissues. According to ${ }^{(19)}$, in vitro cultivated healthy grape varieties expressed better height growth compared to the seedlings infected with GLRaV-3. Similar results were obtained in grape plants infected with GLRaV-3, GFLV, and leafroll virus in vitro ${ }^{(2)}$. The experiments performed with potato plants 
showed that the peroxidase amount increased not only in leaves but also in roots ${ }^{(21)}$. The researchers detected also a correlation between chlorosis degree induced by the virus and amounts of peroxidases. Experiments by Farkas and Stehmann showed that an increase in the activity of peroxidases was associated with a change in their isoenzyme content ${ }^{(22)}$. Thus, a new isoform of peroxidase was observed when the bean plant was treated with actinomycin D in order to increase the resistance of the bean plant to the pathogen infection. Ascorbate peroxidase is an antioxidant enzyme playing a key role in preventing ROS accumulation in higher plants, algae, etc. Our results are consistent with those obtained by others showed that the activities of ascorbate peroxidase and benzidine peroxidase increased in all virus-infected plant samples compared to the healthy plants, which can be attributed to the antioxidant response of plant cells to increased amounts of $\mathrm{H}_{2} \mathrm{O}_{2}$ due to oxidative stress. The activity of ascorbate peroxidase in banana plants infected with BBTV was significantly higher than in healthy plants ${ }^{(23)}$. Similar results were obtained for Hibiscus cannabinus, Nicotiana benthamiana, and sunflower plants infected with Begomovirus, Pepper mild mottle virus and Chlorotic mottle virus, respectively ${ }^{(24)}$. Increased synthesis of this enzyme in the cell enhances the activity of peroxidases, which in turn leads to resistance against ROS and oxidative stress.

Malondialdehyde, a product of lipid peroxidation is considered as an indicator of the destruction of cell membranes ${ }^{(25)}$. There were reports on decreased amounts of carbohydrates and photosynthetic pigments due to viral infections ${ }^{(26)}$. It was established that viral infections adversely affect the process of photosynthesis, which disrupts the normal transport of phloem. In Manihot utilissima Pohl, which is the main food of silkworms, as a result of the disease caused by Cassava mosaic geminivirus (CMG) of the Begomovirus genus in the Geminiviridae family, the leaf surface was reduced, it was twisted and covered with chlorotic spots ${ }^{(27)}$. The virus negatively affected all physiological and biochemical properties, significantly reducing the productivity and quality of leaves. Similar results were obtained for grapevine in our study, the MDA amount significantly increased in healthy plant leaves compared to infected leaves.

The amount of photosynthetic pigments in infected leaves decreased by $30.02 \%$, the amount of soluble proteins decreased by about $16.2 \%$, the total amount of sugars increased by $12.8 \%$. In the plant leaves infected with MYMV, decreased levels of $\mathrm{Chl} \mathrm{a}$ and $\mathrm{Chl} b$ were due to photooxidation through quenching triplet chlorophyll molecules ${ }^{(28)}$. Carotenoids protect the photosynthetic apparatus on the one hand and neutralize ROS on the other ${ }^{(29)}$. In the heat-shocked "Trincadeira" grape variety, carotenoids, along with ascorbate and glutathione, play an important role in clearing the leaves from $\operatorname{ROS}^{(30)}$.

\section{Conclusion}

In summary, the obtained results showed that viral infection caused an increase in the amount of metabolic compounds such as malondialdehyde and hydrogen peroxide and a decrease in the amount of photosynthetic pigments. The results obtained suggest that pathogenesis-induced oxidative burst observed in grapevine is characterized by the increase in the MDA content. Our data indicated a correlation between peroxidase activities and cellular damage provoked by pathogenesis. The considerable increase of peroxidase activities could not stop the deleterious effects of viral infection, but reduced stress severity. Besides, the enhanced activity of peroxidases involved in lignification, compared to control, confirms their participation in the defense mechanism of the plants and the crucial role of the enzymes against phytopathogen attacks.

\section{References}

1) Adiputra J, Kesoju SR, Naidu RA. The Relative Occurrence of Grapevine leafroll-associated virus 3 and Grapevine red blotch virus in Washington State Vineyards. Plant Disease. 2018;102(11):2129-2135. Available from: https://dx.doi.org/10.1094/pdis-12-17-1962-re.

2) Cristina S, Ranieri A, Mike FQ. Antioxidative responses in Vitis vinifera infected by grapevine fanleaf virus. The Journal of Plant Physiology. 2013;70(121). Available from: https://doi.org/10.1016/j.jplph.2012.09.016.

3) Maree HJ, Almeida RPP, Bester R, Chooi KM, Cohen D, Dolja VV, et al. Grapevine leafroll-associated virus 3. Frontiers in Microbiology. 2013;4(82). Available from: https://dx.doi.org/10.3389/fmicb.2013.00082.

4) Bertamini M, Muthuchelian K, Nedunchezhian N. Effect of Grapevine Leafroll on the Photosynthesis of Field Grown Grapevine Plants (Vitis vinifera L. cv. Lagrein). Journal of Phytopathology. 2004;152(3):145-152. Available from: https://dx.doi.org/10.1111/j.1439-0434.2004.00815.x.

5) Borgo M, Angelini E, Flamini R. Effects of grapevine leafrool associated virus 3 on main characteristics of three vineyards. L'enologo. 2003;3:99-110. Available from: https://doi.org/10.1111/aab.12356.

6) Song Y, Hanner RH, Meng B. Probing into the Effects of Grapevine Leafroll-Associated Viruses on the Physiology, Fruit Quality and Gene Expression of Grapes. Viruses. 2021;13(4):593. Available from: https://dx.doi.org/10.3390/v13040593.

7) Riedle-Bauer M. Role of Reactive Oxygen Species and Antioxidant Enzymes in Systemic Virus Infections of Plants. Journal of Phytopathology. 2000;148(5):297-302. Available from: https://dx.doi.org/10.1046/j.1439-0434.2000.00503.x.

8) sa C Carvalho L, cia Vidigal P, ncio SA. Oxidative stress homeostasis in grapevine (Vitis vinifera L.). Frontiers in Environmental Science. 2015;3(20). Available from: https://dx.doi.org/10.3389/fenvs.2015.00020.

9) Irada MH, Durna RA, Ch MA. Aliyev Jalal A. Hydrogen peroxide generation and antioxidant enzyme activities in the leaves and and roots of wheat cultivars subjected to long-term soil drought stress. Photosynthesis Research. 2016;125:279-289. Available from: https://link.springer.com/article/10. 1007/s11120-015-0160-7. 
10) Gara LD, de Pinto MC, Tommasi F. The antioxidant systems vis-à-vis reactive oxygen species during plant-pathogen interaction. Plant Physiology and Biochemistry. 2003;41(10):863-870. Available from: https://dx.doi.org/10.1016/s0981-9428(03)00135-9.

11) Smart RE, Bingham GE. Rapid Estimates of Relative Water Content. Plant Physiology. 1974;53(2):258-260. Available from: https://dx.doi.org/10.1104/ pp.53.2.258.

12) Robert LH, Lester P. Photoperoxidation in isolated chloroplasts. I. Kinetics and stoichiometry of fatty acid peroxidation. Archives of Biochemistry and Biophysics. 1968;125:90654-90655. Available from: https://doi.org/10.1016/0003-9861(68)90654-1.

13) Bellincampi D, Dipierro N, Salvi G, Cervone F, Lorenzo GD. Extracellular H2O2 Induced by Oligogalacturonides Is Not Involved in the Inhibition of the Auxin-Regulated rolB Gene Expression in Tobacco Leaf Explants. Plant Physiology. 2000;122(4):1379-1386. Available from: https://dx.doi.org/10.1104/ pp.122.4.1379.

14) Porra RJ, Thompson WA, Kriedemann PE. Determination of accurate extinction coefficients and simultaneous equations for assaying chlorophylls a and $\mathrm{b}$ extracted with four different solvents: verification of the concentration of chlorophyll standards by atomic absorption spectroscopy. Biochimica et Biophysica Acta (BBA) - Bioenergetics. 1989;975(3):384-394. Available from: https://dx.doi.org/10.1016/s0005-2728(89)80347-0.

15) Wettstein DV. Chlorophyll letale und der submikroskopische Formwechsel der Plastiden. Experimental Cell Research. 1957;12:427-506. Available from: https://doi.org/10.1016/0014-4827(57)90165-9.

16) Yoshiyuki N, Kozi A. Hydrogen Peroxide is Scavenged by Ascorbate-specific Peroxidase in Spinach Chloroplasts. Plant and Cell Physiology. 1981;22:867880. Available from: https://doi.org/10.1093/oxfordjournals.pcp.a076232.

17) Mahalingam R, Shah N, Scrymgeour A, Fedoroff N. Temporal evolution of the Arabidopsis oxidative stress response. Plant Molecular Biology. 2005;57(5):709-730. Available from: https://dx.doi.org/10.1007/s11103-005-2860-4.

18) Gechev T, Gadjev I, Breusegem FV, Inzé D, Dukiandjiev S, Toneva V, et al. Hydrogen peroxide protects tobacco from oxidative stress by inducing a set of antioxidant enzymes. Cellular and Molecular Life Sciences (CMLS). 2002;59(4):708-714. Available from: https://dx.doi.org/10.1007/s00018-002-8459-x.

19) Marković Z, Preiner D, Bošnjak A, Safner T, Stupić D, Željko Andabaka, et al. In vitro introduction of healthy and virus-infected genotypes of native Croatian grapevine cultivars. Open Life Sciences. 2014;9(11):1087-1098. Available from: https://dx.doi.org/10.2478/s11535-014-0337-7.

20) Cui ZH, Bi WL, Pan C, Xu Y, Wang QC. Abiotic stress improves in vitro biological indexing ofGrapevine leafroll-associated virus-3in red grapevine cultivars. Australian Journal of Grape and Wine Research. 2015;21(3):490-495. Available from: https://dx.doi.org/10.1111/ajgw.12146.

21) Milavec M, Gruden K, Ravnikar M, Kovač M. Peroxidases in the early responses of different potato cultivars to infection byPotato virus YNTN. Plant Pathology. 2008;57(5):861-869. Available from: https://dx.doi.org/10.1111/j.1365-3059.2008.01833.x.

22) Farkas GL, Stahmann MA. On the Nature of Changes in Peroxidase Isoenzymes in Bean Leaves Infected by Southern Bean Mosaic Virus. Journal of Phytopathology. 1966;56:669-677. Available from: https://pubmed.ncbi.nlm.nih.gov/5936580/.

23) Tanuja N, Ramanathan A, Vanitha S, Soorianathasundaram K, Kumar KK. Differential Biochemical Response among Banana (Musa spp.) Genotypes against Banana Bunchy Top Virus (BBTV). Current Journal of Applied Science and Technology. 2019;38:1-11. Available from: https://dx.doi.org/10.9734/ cjast/2019/v38i630416.

24) Surajit S. Shooting-harvest interval and physico-chemical properties of banana (Musa AAA cv. Asian Journal of Agricultural and Horticultural Research. 2014;9:40-42. Available from: https://www.cabdirect.org/cabdirect/abstract/20143356593.

25) Hakmaoui A, Perez-Bueno ML, Garcia-Fontana B, Camejo D, Jimenez A, Sevilla F, et al. Analysis of the antioxidant response of Nicotiana benthamiana to infection with two strains of Pepper mild mottle virus. Journal of Experimental Botany. 2012;63(15):5487-5496. Available from: https://dx.doi.org/10. 1093/jxb/ers212.

26) Ananthu N, Umamaheswaran K. Effect of Viral Infection on Carbohydrate and Chlorophyll Contents in Ginger (Zingiber officinale Rosc.). International Journal of Current Microbiology and Applied Sciences. 2019;8(06):862-867. Available from: https://dx.doi.org/10.20546/ijcmas.2019.806.104. doi:10.20546/ijcmas.2019.806.104.

27) Tomy P. Cassava mosaic virus induced physio-biochemical changes in the leaves of tapioca (Manihotutilisima Pohl. International Journal of Plant Protection. 2010;3:31-33. Available from: http://researchjournal.co.in/upload/assignments/3_31-33-1.pdf.

28) Tim MM, Ken LP. Specific common diseases. Florida Plant Disease Management Guide-Tomato 1. vol. 3. University of Florida Florida Cooperative Extension Service.. 2006. Available from: https://plantpath.ifas.ufl.edu/rsol/RalstoniaPublications_PDF/IFASExt2006_FloridaPDMG-V3-53.pdf.

29) Yasushi K. New trends in photobiology: Structures and function of carotenoids in photosynthetic systems. The Journal of Photochemistry and Photobiology B. 1991;9:265-280. Available from: https://doi.org/10.1016/1011-1344(91)80165-E.

30) Carvalho LC, Coito JL, Gonçalves EF, Chaves MM, Amâncio S. Differential physiological response of the grapevine varieties Touriga Nacional and Trincadeira to combined heat, drought and light stresses. Plant Biology. 2016;18:101-111. Available from: https://dx.doi.org/10.1111/plb.12410. 